\title{
Artikel
}

\section{Eichmann, moreel oordelen en strafuitsluitingsgronden}

\author{
De gedeelde verantwoordelijkheid voor verantwoordelijkheid
}

Ik zeg $u$, toon altijd respect

voor het altaar van het recht

en geef het niet

daar maar u winst ziet

minachtend een goddeloze trap ${ }^{1}$

\section{Inleiding}

Tegenwoordig bestaat meer aandacht voor burgers die om uiteenlopende redenen niet goed in staat zijn om zich aan juridische normen te houden, in het bijzonder ook aan strafrechtelijke normen. Het gaat om mensen wier cognitieve vermogens tekortschieten en/of die een onderontwikkeld vermogen van zelfcontrole hebben. Deze ontwikkeling kan worden beschouwd als een zekere mate van erkenning dat de maatschappij - en de overheid in het bijzonder - medeverantwoordelijk is voor het scheppen van de bestaansvoorwaarden waaronder mensen zich kunnen ontplooien tot verantwoordelijke burgers. In dit artikel betoog ik dat deze gedeelde verantwoordelijkheid niet alleen geldt voor de ontwikkeling van de mentale capaciteiten die nodig zijn om de normen van het recht te kunnen volgen, maar ook voor

Johannes Bijlsma is universitair docent strafrecht aan het Willem Pompe Instituut voor Strafrechtswetenschappen en verbonden aan het Utrecht Centre for Accountability and Liability Law (UCALL), Universiteit Utrecht.

1. Aischylos, Het verhaal van Orestes (vert. G. Koolschijn), Amsterdam: Atheneum - Polak \& Van Gennip 2012, p. 168. het bieden van toegang aan burgers tot de materiële normen zelf.

Ten eerste wordt een beknopte schets gegeven van de vermogens van reflexieve zelfcontrole die een voorwaarde zijn voor het kunnen dragen van strafrechtelijke verantwoordelijkheid en de toegenomen aandacht voor degenen die onder invloed van verschillende maatschappelijke factoren in mindere mate over deze vermogens beschikken (2). Vervolgens wordt aan de hand van het zeer extreme voorbeeld van Eichmann (3) betoogd dat de vermogens van reflexieve zelfcontrole intact kunnen zijn, maar strafrechtelijke verantwoordelijkheid problematisch wordt als iemand geen toegang heeft tot de juiste morele en juridische normen (4). Als burgers materiële normen onvoldoende geïnternaliseerd hebben, krijgt de strafrechtelijke handhaving van die normen een (louter) repressief karakter. Dat doet af aan het karakter van het strafrecht als een schuldstrafrecht, maar ook aan de effectiviteit van het strafrecht. Ten slotte wordt betoogd dat niet alleen in zeer extreme situaties van ideologische verblinding burgers de toegang tot de juiste normen kunnen verliezen (5). Vooral op het terrein van de strafuitsluitingsgronden is dat gevaar ook in relatief alledaagse situaties aanwezig, zoals zal worden geillustreerd aan de hand van het noodweerrecht. Daarom bestaat ook een gedeelde verantwoordelijkheid voor de toegang van burgers tot de juiste materiële normen, een verantwoordelijkheid die in belangrijke mate op de schouders van de overheid rust. 


\section{De vermogens van reflexieve zelfcontrole en strafrechtelijke verantwoordelijkheid}

Voor het kunnen dragen van morele en strafrechtelijke verantwoordelijkheid is een voorwaarde dat een subject (1) over het vermogen beschikt om morele en juridische normen te begrijpen en deze toe te passen op een voorgenomen gedragswijze en (2) over het vermogen beschikt om gedrag overeenkomstig deze normen vorm te geven. Deze vermogens worden in ethiek en (straf)rechtsfilosofie in vergelijkbare termen omschreven. ${ }^{2}$ De volgende omschrijving van deze vermogens door de filosoof Wallace laat goed zien dat het om een complex samenstel van psychische capaciteiten gaat, door hem de vermogens van reflexieve zelfcontrole (capacities of reflexive self-control) genoemd:

'To grasp the reason expressed in a moral principle is a more complex task than it might at first appear to be. The understanding required is a kind of participant understanding that goes well beyond the ability to parrot the moral principle in situations it has some relevance. What is needed, rather, is the ability to bring the principle to bear in the full variety of situations to which it applies, anticipating the demands it makes of us in those situations, and knowing when its demands might require adjustment in light of the claims of other moral principles. ${ }^{3}$

'It [het vermogen om gedrag overeenkomstig normen vorm te geven, $\mathrm{JB}$ ] involves, to begin with, a capacity for critical reflection: the ability to step back from one's immediate desires and assess the actions they incline one to perform, in light of the moral reasons one has grasped and accepted. [...] In addition to this capacity for critical reflection, the ability to control one's behavior by reasons also requires the capacity to make choices as a result of deliberation. [...] Someone who lacks the capacity for deliberate choice will therefore lack the ability to control what she does by grasping moral reasons. [...] Finally it is necessary that the agent should have some capacity to translate her choices into behavior.'4

2. Zie bijvoorbeeld: H.L.A. Hart, Punishment and responsibility. Essays in the philosophy of law, Oxford: Oxford University Press 2008, p. 227; F. de Jong, 'Schuld en de Ander: pleidooi voor een herwaardering van het strafrechtelijke schuldbegrip'; Delikt en Delinkwent 2020, p. 344-345; A.W.M. Mooij, Toerekeningsvatbaarheid. Over handelingsvrijheid, Amsterdam: Boom 2004, p. 116-124, 151-152; K. Rozemond, Het menselijke kwaad, Amsterdam: Boom 2020, p. 64-65.

3. R.J. Wallace, Responsibility and the moral sentiments, Cambridge: Harvard University Press 1994, p. 157.

4. Wallace 1994 , p. 158. De capacity for critical reflection lijkt overeen te komen met wat Mooij (2004, p. 116-124, 151-152) het 'vermogen tot overleg' noemt, de aantasting waarvan tot ontoerekenbaarheid zou moeten leiden.
Het strafrecht veronderstelt de aanwezigheid van voldoende ontwikkelde vermogens van reflexieve zelfcontrole bij alle rechtssubjecten vanaf (althans in Nederland) de leeftijd van twaalf jaar (artikel $486 \mathrm{~Sv}$ ). ${ }^{5}$ In uitzonderingsgevallen kan bijvoorbeeld een stoornis ertoe leiden dat een verdachte niet in staat is de wederrechtelijkheid van zijn handeling in te zien of om zijn gedrag te conformeren aan de eisen van de wet (art. $39 \mathrm{Sr}$ ). Ook dan gaat het echter doorgaans om verdachten die in het algemeen wel tot moreel en juridisch redeneren in staat zijn. Zo kan een psychose tot gevolg hebben dat een verdachte ten aanzien van een concreet feit niet kon begrijpen dat hij in strijd met het strafrecht handelde, maar betekent dat niet zonder meer dat hij in het algemeen niet over vermogens van reflexieve zelfcontrole beschikt. ${ }^{6}$ Slechts bij extreme psychische stoornissen - bijvoorbeeld zware ontwikkelingsstoornissen of vergevorderde dementie - kan worden aangenomen dat de vermogens van reflexieve zelfcontrole (vrijwel) geheel afwezig zijn. Zo'n verdachte is in feite a priori ontoerekenbaar voor zijn of haar handelen. ${ }^{7}$

Hoewel het (straf)recht de vermogens van reflexieve zelfcontrole vooronderstelt, zijn deze vermogens niet bij iedereen in gelijke mate tot ontplooiing gekomen. De vermogens van reflexieve zelfcontrole zijn ten dele het resultaat van leerprocessen, waardoor opvoeding en andere factoren in de jeugd van invloed zijn op de mate waarin zij tot wasdom komen. ${ }^{8}$ Bij degenen die over deze vermogens beschikken, worden zij beïnvloed door omgevingsfactoren. Het hebben van problematische schulden, bijvoorbeeld, is van invloed op de cognitieve vermogens en het vermogen om gedrag te controleren. ${ }^{9}$ Het besef dat het recht in het algemeen in grote mate abstraheert van de ongelijke verdeling van deze vermogens, is de afgelopen jaren groter geworden. ${ }^{10}$ In de

5. De Jong (2020, p. 345) wijst erop dat het strafrecht 'zich doorgaans weinig [bekommert] om de vraag of individuele justitiabelen ook echt (voldoende) met die vermogens zijn begiftigd'. Dit zou te herleiden zijn tot de liberale en individualistische politieke ideologie onder invloed waarvan het klassieke strafrecht tot stand is gekomen en dat uitging van de zelfbewuste bourgeois. Tegenwoordig zou onder invloed van het neoliberalisme opnieuw sterk de nadruk worden gelegd op het vermogen van het individu om zijn of haar gedrag te controleren, ongeacht de vraag of de concrete dader over deze vermogens beschikt. De Jong pleit daarom voor een herwaardering van de 'binnenzijde' van de schuld.

6. Zie daarover J. Bijlsma, 'Wederrechtelijkheid of morele ongeoorloofdheid: welk inzicht moet de ontoerekenbare verdachte ontberen?', Delikt en Delinkwent 2019, p. 801-814.

7. J. Bijlsma, Stoornis en strafuitsluiting. Op zoek naar een toetsingskader voor ontoerekenbaarheid (diss. Amsterdam VU), Oisterwijk: Wolf Legal Publishers 2016, p. 233-244.

8. De Jong 2020, p. 348-353; Wallace 1994, p. 231-234

9. W. Tiemeijer, Eigen schuld? Een gedragswetenschappelijk perspectief op problematische schulden (verkenning WRR), Amsterdam: Amsterdam University Press 2016. Zie ook G. van Beek, V. de Vogel en D. van de Mheen, 'Financiële problematiek als belemmering voor de re-integratie van ex-delinquenten. Een onderzoek onder reclasseringswerkers en hun cliënten', Justitiële Verkenningen 2020/1, p. 86-104.

10. Een reeks rapporten en verkenningen van de Wetenschappelijke Raad voor het Regeringsbeleid ('WRR') is van invloed geweest op het ontstaan van het besef dat de overheid vaak te veel verwacht van het vermogen van burgers om rationeel te handelen en gedrag te controleren. Zie onder meer: Met kennis van gedrag beleid maken (rapport WRR), Amsterdam: Amsterdam University Press 2014; Weten is 
toepassing van het sanctierecht is een ontwikkeling te ontwaren om althans bij een deel van de delinquenten de ontwikkeling van de vermogens van reflexieve zelfcontrole te stimuleren. ${ }^{11}$ Eenvoudige voorbeelden van sancties die de vermogens van reflexieve zelfcontrole moeten beïnloeden, zijn door de Reclassering in het kader van voorwaardelijke sancties verzorgde cursussen, zoals een cognitievevaardighedentraining of een training agressiebeheersing. Het sanctierecht kan deze vermogens echter ook in negatieve zin beïvloeden. Vooral detentie gaat gepaard met een achteruitgang van het vermogen van zelfcontrole. ${ }^{12}$

Binnen het bestek van dit artikel kan niet uitvoerig worden ingegaan op de kenmerken van de vermogens van reflexieve zelfcontrole, de ontwikkeling ervan en factoren die het functioneren ervan beïnloeden. Als het echter zo is dat de capaciteiten die ten grondslag liggen aan strafrechtelijke verantwoordelijkheid in ieder geval ten dele samenhangen met omgevingsfactoren, draagt niet alleen het individu verantwoordelijkheid voor het ontwikkelen en onderhouden van deze vermogens, maar dient ook 'de maatschappij' zorg te dragen voor gunstige ontwikkelings- en bestaansvoorwaarden voor deze vermogens, bijvoorbeeld door goed onderwijs aan te bieden, armoede en problematische schulden te voorkomen en adequate geestelijke gezondheidszorg in stand te houden.

Hoe beter de vermogens van reflexieve zelfcontrole in een samenleving als geheel zijn ontwikkeld, hoe beter burgers in staat zijn morele en juridische normen op hun gedrag toe te passen en om daarnaar te handelen. In die situatie hoeft minder vaak op het strafrecht te worden teruggegrepen. Burgers zullen minder vaak de wet overtreden omdat zij minder vaak beoordelingsfouten maken of hun zelfcontrole verliezen. Tegelijkertijd zal in de gevallen waarin dat wél noodzakelijk blijkt te zijn de verdachte sterker op zijn of haar verantwoordelijkheid kunnen worden aangesproken. Zijn de vermogens van reflexieve zelfcontrole in een samenleving als geheel echter slechts matig ontwikkeld, dan ervaren burgers meer moeite om zich aan de strafwet te houden. $\mathrm{Zij}$ kunnen in mindere mate de regels begrijpen en toepassen en hun gedrag daarnaar vormen. Het strafrecht

nog geen doen. Een realistisch perspectief op zelfredzaamheid (rapport WRR), Den Haag: WRR 2017.

11. Rose noemt deze ontwikkeling in het Westerse strafrecht 'responsabilisering': 'to reconstruct self-reliance in those who are excluded. [...] This ethical reformulation opens the possibility for a whole range of psychological techniques to be recycled in programmes for governing the exluded.' 'Includerende' sancties zijn erop gericht delinquenten de vaardigheden bij te brengen die nodig zijn om weer verantwoordelijke leden van de gemeenschap te worden. Deze includerende sancties gaan gepaard met repressief optreden ('exclusie') jegens degenen die niet voor verbetering vatbaar worden geacht. N. Rose, 'Government and control', British Journal of Criminology 2000, p. 321-339. De Jong heeft deze ontwikkeling beschreven voor het Nederlandse strafrecht: $F$. de Jong, 'Responsabilisering in het Nederlandse straf-, sanctie- en detentierecht', Ars Aequi 2017, p. 640-652.

12. S.L.T.J. Ligthart, L.E. van Oploo, J. Meijers, G. Meynen en T. Kooijmans, 'De Nederlandse detentieomgeving en het resocialisatiebeginsel. Implicaties van neuropsychologisch onderzoek', Nederlands Juristenblad 2018, p. 924-930. zal vaker moeten worden ingezet omdat burgers de strafrechtelijke gedragsnormen frequenter overtreden. Paradoxaal genoeg zullen zij zich juist minder aangesproken voelen omdat zij minder goed begrijpen wat zij fout hebben gedaan of hoe zij anders hadden kunnen handelen. De strafrechtelijke handhaving krijgt daardoor een meer repressief karakter. Met repressie bedoel ik in dit verband het handhaven van juridische normen door leedtoevoegende sancties waarvan de rechtvaardiging niet of slechts in beperkte mate wordt begrepen door rechtssubjecten. Het schuldkarakter van het strafrecht is daarom niet alleen een kwestie van de inrichting van het materiële strafrecht, het veronderstelt ook burgers die schuld kunnen dragen en die gedijen beter in een samenleving waarin de ontwikkelingsvoorwaarden voor de vermogens van reflexieve zelfcontrole gunstig zijn.

\section{De casus Eichmann}

Het menselijke kmaad van Rozemond bevat een fijnzinnige historische, filosofische en juridische analyse van de misdaden van en de rechtszaak tegen Adolf Eichmann. ${ }^{13}$ Rozemond probeert daarmee het kwaad in het algemeen en het specifieke, extreme kwaad van de nazi's te begrijpen. De analyse van Rozemond van de casus Eichmann met de bekende banaliteitsthese van Arendt als aanknopingspunt laat zien dat het beschikken over vermogens van reflexieve zelfcontrole alléén onvoldoende is om het schuldkarakter van het strafrecht ten volle te garanderen. Een noodzakelijke voorwaarde voor het schuldstrafrecht is tevens dat recht en moraal niet te ver uiteenlopen en dat burgers in voldoende mate toegang hebben tot de materiële morele en strafrechtelijke normen die hun gedrag zouden moeten sturen.

Rozemond begint zijn analyse met de beschrijving van een 'standaardtheorie' van het kwaad. ${ }^{14}$ Deze standaardtheorie houdt in dat een menselijke gedraging een manifestatie van het kwaad is als deze verwoestende gevolgen heeft voor de levens van anderen en in strijd is met een fundamentele morele norm, bijvoorbeeld het gebod om niet te doden. De dader moet zich bovendien bewust (kunnen) zijn van het kwaad dat hij aanricht. Het bewustzijn van de geschonden norm is volgens Rozemond 'de kern van het menselijke kwaad'. ${ }^{15}$ Een doorsneemisdadiger is bekend met de normen die op zijn of haar gedrag van toepassing zijn en zal deze valk in het algemeen ook onderschrijven, maar laat zijn of haar eigen belang (in de vorm van bijvoorbeeld geld, macht of lustbevrediging) zwaarder wegen dan het maatschappelijke belang om zich aan de geldende normen te houden. In dit bewustzijn van de normschending is de grondslag voor morele (en juridische) verantwoordelijkheid gelegen. Deze twee vereisten kunnen met de

13. K. Rozemond, Het menselijke kwaad. Hannah Arendt, Adolf Eichmann en het oordelen over het kwaad, Amsterdam: Boom 2020.

14. Rozemond 2020, p. 51-67.

15. Rozemond 2020, p. 65. 
juridische termen actus reus en mens rea worden aangeduid.

De standaardtheorie veronderstelt dat de dader over bepaalde psychische vermogens beschikt:

'Een vermogen om te denken en te oordelen en vervolgens een vermogen om naar zijn oordelen te handelen. In dat vermogen ligt de vrije wil besloten, opgevat als een vermogen waarmee de dader kan kiezen om wel of niet in overeenstemming met zijn morele inzichten te handelen.' ${ }^{, 16}$

Dit vermogen komt overeen met de in de vorige paragraaf besproken vermogens van reflexieve zelfcontrole. ${ }^{17}$ De banaliteitsthese van Arendt houdt volgens Rozemond in dat zich in Eichmann een bijzondere vorm van het kwaad heeft gemanifesteerd, die niet is in te passen in de standaardtheorie van het kwaad. Hoewel Eichmann een belangrijke rol heeft gespeeld in de Holocaust, was hij volgens Arendt geen overtuigd nazi. Zijn betrokkenheid bij de dood van miljoenen Joden en anderen zou niet het gevolg zijn van het aanhangen van een eliminatief antisemitisme en racisme, maar van blinde gehoorzaamheid. Eichmann wilde handelen als een gezagsgetrouw ambtenaar en voerde de aan hem gegeven bevelen gedachteloos uit, dus zonder daarover een eigen moreel oordeel te vellen. Arendt concludeert daarom dat Eichmann niet met kwade bedoelingen (intent to do prong) handelde. ${ }^{18}$ Eichmann handelde volgens de banaliteitsthese niet met mens rea. ${ }^{19}$

De vraag die Rozemond vervolgens in meerdere hoofdstukken adresseert, ${ }^{20}$ is of dit oordeel van Arendt over Eichmann juist is en ook hoe de 'casus Eichmann' zich verhoudt tot de standaardtheorie van het kwaad.

Het oordeel van Arendt dat Eichmann een bureaucraat was die alleen maar deed wat hem was opgedragen zonder zich daarover een moreel oordeel aan te (kunnen) meten, is volgens Rozemond problematisch. Tijdens zijn politieverhoor had Eichmann opgemerkt dat hij altijd volgens de ethische beginselen van Kant had geleefd. Hij had de Kritiek van de praktische rede aan het begin van de oorlog gelezen en op de terechtzitting in Jeruzalem gaf hij een adequate omschrijving van de categorische imperatief. Hij besefte ook dat hij niet langer volgens de kantiaanse beginselen kon leven toen hij massa-executies van Joden in Oost-Europa had bijgewoond. Deze opmerkingen geven volgens Rozemond aan dat Eichmann in staat was een moreel oordeel over zijn gedrag te vellen.

Tijdens het strafproces in Jeruzalem stelde Eichmann dat hij, nadat hij de massa-executies had bijgewoond en besloten werd tot de fysieke uitroeiing van de Joden, zijn belangstelling voor zijn werk verloor, zijn geweten

16. Rozemond 2020, p. 64.

17. Rozemond baseert zich deels op juridische literatuur.

18. H. Arendt, Eichmann in Jerusalem. A report on the banality of evil, Harmondsworth: Penguin 1976, p. 277

19. Rozemond 2020, p. 42.

20. Rozemond 2020, p. 68-118. De volgende twee alinea's zijn gebaseerd op deze hoofdstukken. uitschakelde en besloot niet meer te doen dan bevelen uit te voeren. Zijn verweer tegen de beschuldiging van betrokkenheid bij de genocide was daarom een beroep op superior orders, naar Israëlisch recht voor nazi's geen strafuitsluitingsgrond, maar een grond voor strafvermindering. De rechtbank in Jeruzalem verwerpt dit verweer. Zij stelt vast dat Eichmann geenszins slaafs bevelen opvolgde. Hij had een aanzienlijke discretionaire bevoegdheid waarbinnen hij zelfstandig kon handelen en spande zich binnen dat raamwerk tot het uiterste in om zo veel mogelijk Joden uit te roeien. Bovendien was Eichmann volgens de rechtbank een overtuigd nazi die handelde met de intentie om het Joodse volk te vernietigen. Hij wordt veroordeeld tot de doodstraf.

De karakterisering van Eichmann als 'banale dader' berust volgens Rozemond op een vergissing. ${ }^{21}$ Uit de processtukken van zijn strafzaak blijkt dat Eichmann tot moreel oordelen in staat was en dat hij met de kwade bedoeling (mens rea) handelde om het Joodse volk te vernietigen. Hij kan volgens Rozemond dus niet worden beschouwd als een manifestatie van 'banaal kwaad' volgens de definitie van Arendt. De 'casus Eichmann' lijkt daarmee weer goed in te passen in de standaardtheorie van het kwaad.

Toch beschouwt ook Rozemond Eichmann als een 'nieuw type crimineel', 22 een type dat volgens de standaardtheorie niet goed te verklaren is. Mogelijk heeft Eichmann aanvankelijk inderdaad bezwaren gehad tegen het vermoorden van Joden. Hij was echter een overtuigd nazi die er gaandeweg de Endlösung van overtuigd raakte dat de Joden fysiek moesten worden uitgeroeid, een overtuiging die hij ook na de oorlog bleef aanhangen. De 'klassieke' moordenaar weet dat hij in strijd handelt met het gebod om te doden, maar doet dat toch omdat hij (bijvoorbeeld) zijn eigenbelang boven de morele en juridische norm laat prevaleren. Eichmann was er echter van overtuigd moreel juist te handelen door de Joden te vermoorden, net als Raskolnikov in Misdaad en straf de (retorische) vraag opwerpt of het vermoorden en beroven van de woekeraarster niet gelegitimeerd is omdat hij zich met het aldus verkregen geld kan wijden aan het algemeen belang: 'Wat denk je, zou één kleine, verwaarloosbare misdaad niet gerechtvaardigd zijn als er tienduizend goede daden tegenover staan?'23 Volgens de antisemitische nazi-ideologie waren de Joden een gevaar voor het voortbestaan van het Duitse volk. Daarom past het kwaad van Eichmann (en wellicht ook dat van Ras-

21. Rozemond 2020, p. 225

22. Rozemond 2020, p. 236

23. F.M. Dostojevski, Misdaad en straf (vert. Hans Boland), Van Oorschot: Amsterdam 2018, p. 79. Overigens is dit weliswaar het bekendste motief, maar uiteindelijk slechts één van de vele mogelijke motieven die in Misdaad en straf voor het handelen van Raskolnikov worden aangedragen: 'Crime and punishment is focused on the solution of an enigma: the mystery of Raskolnikov's motivation. For Raskolnikov himself, as it turns out, discovers that the does not understand why he killed; or rather, more accurately, he becomes aware that the moral purpose inspiring him cannot really explain his behavior.' J. Frank, Dostoevsky. The miraculous years. 1865-1871, Princeton: Princeton University Press 1995, p. 102. Zie ook G. van Roermund, 'Omtrent Raskolnikov', Rechtsfilosofie en Rechtstheorie 2004, p. 3-8. 
kolnikov) volgens Rozemond niet goed in de standaardtheorie: Eichmann was door zijn radicalisering niet in staat in te zien dat hij een kwade handeling verrichtte. Daardoor lijkt de klassieke voorwaarde voor morele en strafrechtelijke verantwoordelijkheid van mens rea niet aanwezig te zijn. ${ }^{24}$

Anders dan in het geval van Raskolnikov vond de radicalisering van Eichmann niet op individueel niveau plaats. Het nazisme beoogde een volledige Ummertung überholter Werte: ${ }^{25}$ de oude gelijkwaardigheidsgedachte van het christendom, de verlichting, de democratie en ook het communisme moest worden vervangen door een op een raciaal superioriteitsdenken gestoelde moraal die geen mededogen toeliet ten aanzien van de tegenstander. ${ }^{26}$ De nazi's probeerden het morele bewustzijn van het Duitse volk door middel van onder andere propaganda en scholing zo te veranderen dat dit volk zou instemmen met de maatregelen en het geweld tegen de 'vijanden van het volk' ${ }^{27}$ 'De ideologie verschafte ook de rechtvaardiging van die handelingen waardoor de betrokkenen bij de genocide niet een kwaad, maar een goed geweten hadden.' ${ }^{28}$ De misdaden van Eichmann en alle andere bij het nazibewind betrokken personen zijn niet los te zien van de veronderstelde rechtvaardiging die de nazi-ideologie en de daarmee verbonden Weltanschauung bood voor hun handelen. ${ }^{29}$

\section{De vermogens van reflexieve zelfcontrole, materiële normen en de samenleving}

Uit de analyse van Rozemond blijkt dat het gebrek aan inzicht van Eichmann in het kwade van zijn handelingen niet het gevolg was van het ontbreken van vermogens van reflexieve zelfcontrole. Eichmann beschikte evident en wellicht zelfs meer dan de gemiddelde burger over het vermogen om op morele regels te reflecteren, om deze op zijn gedrag toe te passen en om in overeenstemming met die regels te handelen. Hij wist dat zijn deelname aan de Holocaust in strijd was met de categorische

24. Rozemond 2020, p. 226.

25. Ontleend aan P. Longerich, Heinrich Himmler. Biographie, München: Pantheon 2008, p. 275. Deze revolutie moest volgens Himmler, in de woorden van Longerich: 'die Totalität aller Lebensäusserungen betreffen, Sitte und Moral, insbesondere die Sexualmoral, Rechtswesen, das gesamte Gebiet der Kultur sowie die soziale Ordnung'.

26. De toespraak van Himmler voor een groep SS-Gruppenführer op 4 oktober 1943 in Posen (tegenwoordig: Poznan) (www. 1000dokumente.de, zoek op <posen>) is daarvan een berucht voorbeeld. Hij zegt daar: 'Wir hatten das moralische Recht, wir hatten die Pflicht gegenüber unserem Volk, dieses Volk [de Joden, JB], das uns umbringen wollte, umzubringen.'

27. Rozemond 2020, p. 134.

28. Rozemond 2020, p. 141. Rozemond (2020, p. 142-152) wijst echter ook op onderzoek waaruit blijkt dat veel 'gewone' Duitsers zich van de moorden distantieerden, deels uit vrees voor vergelding.

29. Zie over het (im)morele wereldbeeld van de nazi's: C. Koonz, The nazi conscience, Cambridge: The Belknap Press of Harvard University Press 2003. imperatief en ging daar toch mee door; niet omdat hij daartoe gedwongen was, maar uit ideologische overtuiging.

Het probleem in het geval van Eichmann bestaat eruit dat hij een alternatief moreel stelsel hanteerde en daarnaar handelde. Daarbij was het niet zo dat hij het morele en strafrechtelijke verbod op het doden van anderen niet onderschreef. Eichmann zal geen voorstander zijn geweest van het afschaffen van het strafrechtelijke verbod op moord en doodslag, zoals de nazi's het strafrecht niet afschaften na de machtsovername. Hij was echter van oordeel dat hij een rechtvaardiging voor zijn betrokkenheid bij de moord op miljoenen Joden had. Die veronderstelde rechtvaardiging van het doden van anderen in strijd met conventionele normen deelt Eichmann met andere ideologische daders zoals de fictieve Raskolnikov en Van der Graaf, Bouyeri en Breivik. ${ }^{30}$

De vraag kan worden opgeworpen of daders die op geen enkele mijze bekend (kunnen) zijn met een conventioneel normenkader nog wel verantwoordelijk kunnen worden gehouden voor het schenden van die normen. In een invloedrijk artikel voert de filosoof Wolf bij wijze van gedachte-experiment JoJo op, de favoriete zoon van Jo de Eerste, een kwaadaardige en sadistische dictator van een klein land. JoJo krijgt van jongs af aan een speciale opleiding en volgt de dagelijkse werkzaamheden van zijn vader. Eenmaal aan de macht vertoont JoJo precies hetzelfde gedrag als zijn vader. Hij laat zijn onderdanen naar willekeur doden en martelen. Wolf concludeert:

'In light of JoJo's heritage and upbringing - both of which he was powerless to control - it is dubious at best that he should be regarded as responsible for what he does. ${ }^{31}$

Als JoJo afgezet en vervolgens berecht zou worden op basis van de conventionele strafrechtelijke normen, kan hij eenvoudig niet begrijpen waarom hij verantwoordelijk wordt gehouden voor moord en mishandeling. Dat onbegrip komt niet voort uit het feit dat hij geen normen op zijn gedrag zou hebben kunnen toepassen of daarnaar niet zou hebben kunnen handelen, maar uit het feit dat

30. Zie over de door Van der Graaf, Bouyeri en Breivik aangedragen rechtvaardigingen voor hun handelen de rechterlijke uitspraken in de tegen hen gevoerde strafzaken: Hof Amsterdam 18 juli 2003, ECLI:NL:GHAMS:2003:AI0123 (Van der Graaf); Rb. Amsterdam 26 juli 2005, ECLI:NL:RBAMST:2005:AU0025 (Bouyeri); Rb. Oslo 24 augustus 2012, TOSLO-2011-188627-24E (Breivik).

31. S. Wolf, 'Sanity and the metaphysics of responsibility', in: F. Schoeman (red.), Responsibility, character and the emotions. New essays in moral psychology, Cambridge: Cambridge University Press 1987, p. 368. Wilson betwist dat de intuïtie van Wolf over het gebrek aan verantwoordelijkheid van JoJo voor zijn daden algemeen gedeeld wordt: 'My [cursivering JB] intuition is that JoJo is responsible for his behavior, some of which involves deliberately oppressing his subjects. Someone may wish to differ, but I suspect that most people would agree. Surprisingly, my intuition flies in the face of Wolf's analysis.' P.E. Wilson, 'Sanity and irresponsability', Philosophy, Psychiatry, \& Psychology 1996, 296. Zie over de bruikbaarheid van de analyse van Wolf voor theorievorming over ontoerekenbaarheid: G. Meynen, 'An ethical framework for assessments of criminal responsibility: Applying Susan Wolf's account of sanity to forensic psychiatry', International Journal of Law and Psychiatry 2012, p. 298-304 
hij door zijn levensloop geheel onbekend is met de conventionele morele en strafrechtelijke normen die willekeurig geweld verbieden. Iemand verantwoordelijk houden voor normen die hij niet kon kennen ten tijde van zijn handelen, is in strijd met het uitgangspunt van strafrechtelijke verantwoordelijkheid dat een verdachte ten tijde van het strafbare feit ten minste de geschonden normen moet hebben kunnen kennen. Als een verdachte als gevolg van verschoonbare rechtsdwaling in strijd met het recht handelt, kan hij zich volgens Nederlands recht bijvoorbeeld op afwezigheid van alle schuld beroepen. ${ }^{32}$ Het uitgangspunt in het gedachte-experiment is dat de conventionele normen voor JoJo volledig ontoegankelijk waren. Hij kan in dat geval niet volgens de conventionele morele en strafrechtelijke normen verantwoordelijk worden gehouden en worden gestraft (hij kon zijn gedrag immers niet naar de normen richten en kon niet begrijpen dat hij iets fout deed), hij zal hooguit op basis van zijn gevaarlijkheid preventief kunnen worden gedetineerd. Het strafrecht heeft in dat geval uitsluitend een repressieve functie. ${ }^{33}$

JoJo bestaat alleen in een gedachte-experiment. In werkelijkheid is het morele bewustzijn van daders vele malen complexer. ${ }^{34}$ Raskolnikov, Eichmann, Van der Graaf, Bouyeri en Breivik verwerpen de conventionele juridische normen bewust en daarin bestaat een grondslag voor hun strafrechtelijke verantwoordelijkheid. Zij waren bekend met de strafrechtelijke normen en moeten in staat worden geacht de door hen verworpen normen op hun gedrag toe te passen. Daardoor kunnen zij volgens Rozemond worden aangesproken op hun misdaden en gestraft worden als burgers die verantwoordelijk zijn voor de keuzes die zij hebben gemaakt. ${ }^{35}$

Als echter moet worden aangenomen dat een dader door ideologische verblinding in het geheel niet in staat kan zijn het kwade van zijn of haar handelen in te zien, is de vestiging van strafrechtelijke verantwoordelijkheid volgens de conventionele strafrechtelijke normen problematisch. ${ }^{36}$ Voor Eichmann gold dat hij nog toegang had tot een alternatief moreel en juridisch stelsel, op basis waarvan verantwoordelijkheid kon worden gevestigd. Als de morele revolutie van de nazi's echter niet in 1945 ten einde was gekomen maar voltooid had kunnen worden, was een generatie opgegroeid wier enige morele referentiekader het nazisme zou zijn. De nazipropagan$\mathrm{da}$, in het bijzonder in het onderwijs, was expliciet gericht op het laten opgroeien van zo'n generatie. ${ }^{37} \mathrm{Dit}$

32. HR 14 februari 1916, NJ 1916, p. 681; HR 22 november 1949, NJ 1950/180 m.nt. Röling.

33. Een veroordeling zou er ook toe kunnen dienen om de verdachte de juiste normen bij te brengen (Rozemond 2020, p. 269). Naar geldend recht is het echter zo dat degene die verschoonbaar dwaalt over de wederrechtelijkheid van het feit, niet gestraft mag worden om hem of haar alsnog deze normen in te prenten.

34. Juist deze complexiteit wordt in Misdaad en straf gethematiseerd (zie voetnoot 23 )

35. Rozemond 2020, p. 260-261.

36. Vgl. Arendt 1977, p. 277-279; Rozemond 2020, p. 228.

37. Zie Koonz 2003, p. 131-162. Koonz (2003, p. 131) citeert een rede van Hitler, waarin deze zegt: 'Youth, he said, "has been consigned to us and has become our body and soul. They live in this proud Germany of the swastika and will never again let it be ripped from their hearts."' zou, ervan uitgaande dat de omwenteling totaal zou zijn, een generatie JoJo's hebben opgeleverd, die niet in staat zou zijn het kwade van haar handelen in te zien. De klassieke morele en juridische voorwaarde voor verantwoordelijkheid van inzicht in het kwade, respectievelijk de wederrechtelijkheid van het handelen (mens rea) ontbreekt. ${ }^{38}$ Gezien de gebleken extreme gevaarlijkheid van deze geïndoctrineerde daders kan dan nog wel een rechtvaardiging bestaan voor strafrechtelijke maatregelen die de maatschappij beogen te beschermen. ${ }^{39}$ Deze maatregelen vinden hun grondslag echter niet in de schuld van de dader, maar in preventie.

\section{Moreel oordelen en noodweer}

De zeer extreme voorbeelden van Eichmann, Van der Graaf, Bouyeri en Breivik en de fictieve Raskolnikov en JoJo laten scherp zien dat voor strafrechtelijke verantwoordelijkheid niet alleen de vermogens van reflexieve zelfcontrole van belang zijn. Burgers moeten, om verantwoordelijk te kunnen worden gehouden, ten minste toegang hebben tot de juiste normen. De casus Eichmann en het voorbeeld van JoJo laten zien welke rol de samenleving - en de overheid als representant van de samenleving - daarin vervult. Uit de analyse uit de voorgaande paragraaf volgt dat morele en juridische normen niet te ver uiteen mogen lopen. Als binnen de samenleving tot op zekere hoogte aanvaarde morele normen burgers een rechtvaardiging bieden voor gedrag dat in strijd is met de conventionele juridische normen, zal het voor hen moeilijker worden zich aan de strafrechtelijke normen te houden. Dat suggereert dat strafrecht en moraal sterk verknoopt zijn, of althans zouden moeten zijn.

Aan de hand van een analyse van de strafuitsluitingsgrond noodweer wil ik laten zien dat de verantwoordelijkheid van de overheid verder gaat en ook complexer is dan alleen de plicht om materieelstrafrechtelijke normen te publiceren. ${ }^{40}$ Tevens wil ik aannemelijk maken dat deze complexiteit zich juist doet gelden op het terrein van de strafuitsluitingsgronden. In deze paragraaf wil ik laten zien dat de mogelijkheid om burgers verantwoordelijk te houden voor overtreding van het verbod op

38. Overigens is het risico op het opgroeien van een hele generatie die onbekend is met het verbod op genocide en de andere misdrijven tegen de menselijkheid veel onwaarschijnlijker geworden na de ontwikkeling van het internationale strafrecht sinds de processen in Neurenberg (Rozemond 2020, p. 241-242). Toch kan dit fenomeen zich nog steeds manifesteren, zoals in het recente verleden de systematische indoctrinatie van jonge kinderen door Islamitische Staat heeft laten zien. Zie daarover J.G. Horgan, M. Taylor, M. Bloom en C. Winter, 'From cubs to lions: a six stage model of child socialization into the Islamic State', Studies in Conflict and Terrorism 2017, p. 645-655.

39. Rozemond 2020, p. 229-230.

40. Deze politieke verantwoordelijkheid kan in verband worden gebracht met wat Bijlsma noemt the politics of imagination bij Spinoza en Hume: R. Bijlsma, Spinoza, Hume, and the politics of imagination. Naturalism, narrative, enlightenment (diss. Antwerpen), Antwerpen: 2015, p. 211. 
geweld kan eroderen onder invloed van maatschappelijke factoren. Daarbij wordt als voorbeeld het politieke discours over noodweer gebruikt. Daarmee is niet bedoeld om dit discours in verband te brengen met het nazisme. Bedoeld is juist om te laten zien dat spanning tussen morele en strafrechtelijke rechtvaardiging van geweld ook op minder extreme wijze kan ontstaan dan door radicale ideologie. Voldoende daarvoor is dat de strafrechtelijke normen in het morele discours van een zekere ambiguiteit worden voorzien. Een ander verschil met de analyse in de vorige paragraaf is dat het in deze paragraaf niet om de vraag gaat of een verdachte wel of niet verantwoordelijk kan worden gehouden. Zoals het in de in paragraaf 2 beschreven ontwikkeling om burgers gaat wier minder goed ontwikkelde vermogens tot reflexieve zelfcontrole het moeilijker, maar niet onmogelijk maken om zich aan de strafrechtelijke normen te houden, gaat het hier om de situatie waarin ambigue gedragsnormen het naleven van de strafwet bemoeilijken, ook voor burgers wier vermogens tot reflexieve controle in voldoende mate tot ontwikkeling zijn gekomen.

De meest basale morele norm is (afhankelijk van welke telling gevolgd wordt) het vijfde of zesde gebod: 'Gij zult niet doodslaan', waarvan overtreding strafbaar is gesteld in titel XIX van het tweede boek van het Wetboek van Strafrecht. Dit lijkt een hard and fast rule: het is niet toegestaan om een ander van het leven te beroven en - iets breder opgevat - om geweld tegen een ander te plegen. Deze norm is zo universeel dat aangenomen mag worden dat iedereen daar toegang toe heeft, hoewel - zoals de vorige paragraaf heeft laten zien - uitzonderingen (JoJo) daarop niet ondenkbaar zijn. Zelfs Eichmann zal echter, zoals eerder opgemerkt, deze norm in algemene zin hebben onderschreven.

Het probleem is dat het verbod op het doden van een ander uitzonderingen kent. De voorbeelden die in de vorige paragrafen werden gegeven laten zien waar een ontsporing van het morele oordeel dat geweld gerechtvaardigd is in extremis toe kan leiden. Het materiële strafrecht kent echter ook diverse uitzonderingen op het verbod om dodelijk geweld toe te passen, waardoor de prima facie duidelijke regel dat geweld verboden is, wordt gecompliceerd.

Militairen of politieagenten hebben onder bepaalde omstandigheden de bevoegdheid om geweld toe te passen. De in de praktijk belangrijkste uitzondering op het verbod op doden en - in het verlengde daarvan - op het aantasten van de fysieke integriteit van anderen in het algemeen, is echter handelen uit noodweer. Van de burger die zich in een noodweersituatie bevindt, wordt veel gevergd. Hij (of zij) moet in een zeer kort tijdsbestek de situatie correct inschatten als een situatie waarin hij wordt of dreigt te worden aangevallen, vervolgens moet hij beoordelen of hij nog kan ontkomen en, zo nee, beslissen hoe hij zich zal verdedigen en voorkomen dat hij naar een te zwaar middel grijpt. Ten slotte moet hij handelen overeenkomstig de voorgenomen gedragslijn en zich niet door zijn emoties laten meeslepen. ${ }^{41}$ Daarbij gaat van de situatie een sterke druk op de betrokkene uit. Een foute inschatting van de feitelijke situatie kan lichamelijk letsel tot gevolg hebben, een foute juridische beoordeling daarvan kan tot strafrechtelijke aansprakelijkheid leiden. De burger zal daarbij vaak niet volledig op de hoogte zijn van de materiële normen die gelden. Zo zal hij doorgaans onbekend zijn met het juridische onderscheid tussen een onmiddellijk dreigende aanranding en een situatie waarin slechts sprake is van de vrees om te worden aangerand. Hetzelfde geldt voor de finesses van het onttrekkingsvereiste en de vereisten voor een proportionele verdediging. De gemiddelde burger zal in een noodweersituatie waarschijnlijk sterker varen op morele intuitie dan op kennis van het juridische normenkader. Het noodweerrecht biedt daarom ook ruimte voor het maken van fouten. ${ }^{42}$ Het erkent dat juist in een nijpende en bedreigende situatie de vermogens van reflexieve zelfcontrole kunnen falen, hetzij door een verkeerde beoordeling (putatieve noodweer), hetzij door een gebrekkige zelfcontrole (noodweerexces). De beoordeling of de toepassing van geweld is toegestaan, is vele malen complexer dan de schijnbare hard and fast rules van het vijfde (of zesde) gebod en de strafbaarstellingen van titel XIX boek 2 suggereren. Een van de weinige scherpe normen die het strafrecht in het algemeen en het noodweerrecht in het bijzonder wél kent, is het verbod van eigenrichting. ${ }^{43}$ Een op het oog verdedigende handeling die in feite een wraakneming is, is ondubbelzinnig verboden. ${ }^{44}$

De afgelopen twee decennia is een politiek discours over noodweer ontstaan waardoor het op zichzelf al complexe normenstelsel dat achter de noodweer schuilgaat, verder gecompliceerd is doordat een morele rechtvaardiging lijkt te worden geboden voor de toepassing van geweld die in strijd is met het ondubbelzinnige juridische

41. In een overzichtsarrest van 22 maart 2016 (ECLI:NL:HR:2016:456) heeft de Hoge Raad zijn jurisprudentie over noodweer in hoofdlijnen weergegeven. Deze jurisprudentie heeft echter ook een sterk casuïstische inslag, die hier niet kan worden weergegeven en die ook in het overzichtsarrest niet volledig tot uitdrukking komt.

42. Over subsidiariteit en proportionaliteit overweegt de Hoge Raad (22 maart 2016, ECLI:NL:HR:2016:456) in r.o. 3.5.1: 'Zeker bij deze eisen kan de persoon van degene die zich op noodweer beroept, van belang zijn. Van de ene persoon mag bijvoorbeeld op grond van zijn hoedanigheid of bijzondere vaardigheden meer worden gevergd op het vlak van de proportionaliteit dan van een ander.'

43. C. Kelk/F. de Jong, Studieboek materieel strafrecht, Deventer: Wolters Kluwer 2019, p. 1-2.

44. De Hoge Raad stelt in het overzichtsarrest van 22 maart 2016 (ECLI:NL:HR:2016:456) in r.o. 3.3: 'Een beroep op noodweer kan niet worden aanvaard ingeval de gedraging van degene die zich op deze exceptie beroept, noch op grond van diens bedoeling, noch op grond van de uiterlijke verschijningsvorm van zijn gedraging kan worden aangemerkt als "verdediging", maar - naar de kern bezien - als aanvallend moet worden gezien, bijvoorbeeld gericht op een confrontatie of deelneming aan een gevecht.' In deze overweging kan het verbod op eigenrichting en wraakneming worden gelezen (vgl. R. Jansen, 'Verdedigingswil bij noodweer', Delikt en Delinkwent 2015, p. 444). In de lagere rechtspraak wordt een beroep op noodweer soms expliciet verworpen omdat sprake zou zijn van wraakneming. Zie bijv. Rb. Rotterdam 11 april 2006, ECLI:NL:RBROT:2006:AW5184; Rb. Limburg 31 mei 2013, ECLI:NL:RBLIM:2013:CA1648; Rb. Oost-Brabant 13 februari 2020, ECLI:NL:RBOBR:2020:740. 
verbod op eigenrichting. Politici en ambtsdragers hebben dit verbod - dat in feite een verbod op wraakneming is - gerelativeerd, of op zijn minst de suggestie gewekt dit te relativeren. Dit begon in 2002 met de vermaarde 'gigantische rotschop' die toenmalig minister van Binnenlandse Zaken Remkes wilde uitdelen aan enkele geweldplegers ${ }^{45}$ en de boete die prins Bernhard betaalde van een paar supermarktmedewerkers die een al geboeide overvaller bleven schoppen en slaan. ${ }^{46}$ Toenmalig minister van Veiligheid en Justitie Opstelten vond dat men 'vrij ver mag gaan' in het geval van noodweer tegen een inbreker, ${ }^{47}$ terwijl een voormalig burgemeester van Zaltbommel aanbeval: 'Sla ze maar verrot.' ${ }^{48}$ Weer iets later had staatssecretaris Teeven het over het 'inbrekersrisico' op letsel. ${ }^{49}$ Premier Rutte merkte kort na de jaarwisseling 2018-2019 over relschoppers op dat hij ze 'liefst allemaal persoonlijk in elkaar [zou] slaan' ${ }^{50}$

$\mathrm{Nu}$ zijn dit geen expliciete oproepen tot ongelimiteerde wraakneming, en wordt ook regelmatig de disclaimer toegevoegd dat eigenrichting 'natuurlijk' niet mag, maar de hard and fast rule van het verbod op eigenrichting wordt op zijn minst gerelativeerd door personen op wier gezag de burger vaart en ook zou moeten kunnen varen. De betrokken gezagsdragers weten vermoedelijk dat er een grote kans is dat burgers hun uitspraken zo zullen opvatten. $^{51}$

Juridisch gezien geldt het verbod op eigenrichting echter onverkort en kan het ook niet gerelativeerd worden zonder het instituut van de overheidsrechtspraak zelf te ondergraven. Juist het verbod op wraakneming staat - letterlijk - aan de basis van de Westerse rechtsorde. Zowel in de Odyssee als in de Oresteia komt de dodelijke cyclus van wraak en geweld pas tot een einde door het sluiten van een verdrag en - in de Oresteia het in het leven roepen van een rechtsprekende instantie. Het verbod op wraakneming kan daarom niet door de overheidsrechter worden gebagatelliseerd zonder zijn eigen legitimiteit aan te tasten. ${ }^{52}$

De beoordeling of zelfverdediging is toegestaan vergt een complex samenspel tussen de vermogens van reflexieve zelfcontrole en materiële juridische en morele normen, een oordeel dat bovendien in een zeer kort

45. 'Remkes zou zelf "een rotschop" hebben uitgedeeld', Algemeen Dagblad 25 oktober 2002.

46. 'Prins Bernhard betaalt boete $\mathrm{AH}$-achtervolger', De Volkskrant 1 maart 2001.

47. "'Ik hou niet van deftig gedoe, ik ga voor de volle mep", Interview Ivo Opstelten, minister van Veiligheid van Justitie', De Volkskrant 20 november 2010.

48. 'Burgemeester van Zaltbommel: "Sla overvallers maar verrot"', Brabants Dagblad 22 november 2010.

49. 'Teeven: omgekomen inbreker nam zelf risico', NRC Handelsblad 26 september 2012

50. 'Rutte zou raddraaiers "het liefst allemaal in elkaar staan"', Trouw 11 januari 2019.

51. Een redactioneel commentaar in NRC Handelsblad ('Teeven op het slappe koord', NRC Handelsblad 27 september 2012) naar aanleiding van enkele van de in de hoofdtekst genoemde uitspraken wordt afgesloten met de conclusie: 'Bepleiten van een weerbare samenleving is code voor wraak.'

52. Vgl. Kelk/De Jong 2019, p. 1-2. tijdsbestek en onder hoge druk moet worden geveld. Het ironische is in zekere zin dat het politieke discours waarin het verbod op eigenrichting wordt gerelativeerd, het goed beoordelen van een noodweersituatie door de burger bemoeilijkt. Het verbod op wraakneming is een eenvoudige regel die ook in noodweersituaties goed te hanteren is. Het relativeren van de regel dat potentieel dodelijk geweld alleen in acuut bedreigende situaties mag worden toegepast en de suggestie dat ook een motief als wraak daarbij een rol mag spelen, opent de deur naar een ruimere rechtvaardiging van gewelddadig handelen. Door de op zichzelf al complexe beoordeling van de vraag of geweld gerechtvaardigd is van morele ambiguiteit te voorzien, neemt de kans op foute beoordelingen van burgers van de juridische legitimiteit van geweldstoepassing toe. Dat geldt temeer doordat de gemiddelde burger bekender zal zijn met het politieke discours dan met de relatief fijnmazige juridische normen van het noodweerrecht. Burgers, ook degenen wier vermogens van reflexieve zelfcontrole in voldoende mate zijn ontwikkeld, zullen vaker beoordelingsfouten maken of sneller hun zelfbeheersing verliezen.

In dit licht is relevant dat de in deze paragraaf beschreven ontwikkeling intussen vergezeld gaat van een discours waarin de strafrechtelijke regulering van geweldstoepassing in een bredere zin wordt vertroebeld met conflicterende morele normen. Toenmalig commentator Baudet beschrijft bijvoorbeeld de gewelddadige rellen tegen de vestiging van een asielzoekerscentrum in Geldermalsen in 2015 als 'noodweer' tegen de veronderstelde 'enorme injectie van criminaliteit in onze samenleving' en de 'schrijftafelmoord' die het asielbeleid teweeg zou brengen. ${ }^{53}$ In 2017 merkt president Trump in een speech voor politieagenten op:

“"When you guys put somebody in the car and you're protecting their head, you know, the way you put their hand over?" Trump said, miming the physical motion of an officer shielding a suspect's head to keep it from bumping against the squad car. "Like, don't hit their head, and they just killed somebody - don't hit their head," Trump continued. "I said, you can take the hand away, okay?" These remarks, coming after Trump talked about towns ravaged by gang violence and described "these thugs being thrown into the back of a paddy wagon," met with applause from at least some of the law enforcement officers gathered for his speech at Suffolk County Community College in New York. ${ }^{\text {'54 }}$

53. Studio Powned, 17 december 2015 (www.npo3.nl/studio-powned/ 17-12-2015/POW_02939196). Complottheorieën die worden aangehangen door een deel van de demonstranten tegen de overheidsmaatregelen ter bestrijding van COVID-19 lijken ook een morele rechtvaardiging te bieden van (zelfs dodelijk) geweld tegen politici. Zie bijvoorbeeld: 'Fantaseren over een moord op Rutte en Wilders', NRC Handelsblad 7 augustus 2020; 'Wat bezielt de coronademonstranten die politici belagen?', NRC Handelsblad 28 augustus 2020.

54. 'Trump tells police not to worry about injuring suspects during arrests', The Washington Post 29 juli 2017 
Het is niet ondenkbaar dat er een moment komt waarop verdachten niet meer goed begrijpen waarop het verbod op eigenrichting berust als het politiek-morele discours waarin geweldstoepassing van een ruimere rechtvaardiging wordt voorzien aanhoudt. Hoewel deze verdachten op zichzelf over voldoende ontwikkelde vermogens tot reflectieve zelfcontrole kunnen beschikken - zij zijn in staat normen op hun gedrag toe te passen en daarnaar te handelen - zijn de materiële normen die zij op hun gedrag toe kunnen passen ambigu. Door de vertroebeling van de juridische norm met conflicterende morele normen neemt de kans op foute beoordelingen van noodweersituaties toe. Dat heeft tot gevolg dat bestraffing van een gewelddadige, wraaklustige verdachte in mindere mate het karakter heeft van het ter verantwoording roepen van een burger die beseft welke norm hij heeft overtreden en meer het karakter krijgt van repressie. Tegelijkertijd kan dan verwacht worden dat burgers minder terughoudend zullen handelen in noodweersituaties. Het aantal gevallen waarin wraakneming een rol speelt zal toenemen en daarmee zal het algehele geweldsniveau in de samenleving stijgen. Politici dienen zich er daarom van bewust te zijn dat een relativering van het verbod op eigenrichting door een met dat verbod conflicterende morele rechtvaardiging voor geweld te bieden niet vrijblijvend is. De grimmige aanloop naar de Amerikaanse presidentsverkiezeningen van 2020 lijkt deze stelling te onderstrepen. Politici vervullen een belangrijke rol in het bieden van toegang aan burgers tot het juiste normenkader, ${ }^{55}$ welke toegang de burger nodig heeft om zich aan de door de overheid zelf gestelde normen te houden en op basis waarvan hij ook voor de overheidsrechter ter verantwoording kan worden geroepen.

\section{Conclusie: de gedeelde verantwoordelijkheid voor verantwoordelijkheid}

Om burgers strafrechtelijk verantwoordelijk te kunnen houden moeten concrete ontwikkelings- en bestaansvoorwaarden voor het kunnen dragen van verantwoordelijkheid aanwezig zijn. Het is daarbij onvoldoende dat burgers de vermogens kunnen ontwikkelen om gedrag moreel en juridisch te beoordelen en om naar dat oordeel te kunnen handelen. De maatschappelijke omstandigheden moeten ook zodanig zijn dat de burger in voldoende mate toegang heeft tot de materiële normen die op gedrag van toepassing zijn. Waar het gaat om de vaak betrekkelijk eenvoudige verbodsnormen van de meest ernstige misdrijven zal die toegang doorgaans bestaan. De materiële normen en de wijze waarop deze onderling moeten worden afgewogen zijn echter veel minder scherp bij de uitzonderingen op de verbodsnormen - de strafuitsluitingsgronden. Handhaving van het schuldkarakter van het strafrecht is daarom ook afhankelijk van het bieden van toegang aan burgers tot het complex van normen dat voorziet in een rechtvaardiging of verontschuldiging van anderszins strafbaar gedrag. Daarvoor is de maatschappij in brede zin verantwoordelijk. Zoals de laatste tijd het besef is doorgedrongen dat de vermogens van reflexieve zelfcontrole niet evenredig over de bevolking zijn verdeeld en dat maatschappelijke omstandigheden daarop van invloed zijn, zo zou ook het besef moeten rijzen dat toegang tot de juiste materiële normen een bestaansvoorwaarde vormt voor burgers die in staat zijn verantwoordelijkheid te dragen. Het bieden van die toegang is niet alleen een overheidstaak, maar is bijvoorbeeld ook in belangrijke mate een kwestie van opvoeding en scholing. De overheid heeft echter wel een bijzondere verantwoordelijkheid, mede omdat de burger zich uiteindelijk voor de overheidsrechter moet verantwoorden voor overtreding van de strafrechtelijke normen. Het politieke discours over noodweer laat zien dat een effectieve handhaving van strafrechtelijke normen en van het schuldkarakter van het strafrecht maar beperkt ruimte biedt aan ambts- en gezagsdragers om de materiële juridische normen te relativeren met een beroep op conflicterende morele normen. kleine) deel van hun aanhang dat geneigd is tot geweld over te gaan: 'the researchers also found that when those prone to violence were read a statement by either Biden or Trump condemning violence, they became 20 percent less likely to support political violence. The more partisan, the greater the effect. "Without a message of anti-violence, the strong partisans are more violent," Lilliana Mason, an associate professor of government and politics at the University of Maryland, tells me.' D. Milbank, 'Cornered, Trump tries to foment a race war', The Washington Post 1 september 2020. 